\title{
РОЗВИТОК ТРУДОВОГО ЗАКОНОДАВСТВА УКРАЇНИ ЗА ЧАСІВ ІСНУВАННЯ СРСР
}

Обушенко Н. М.

У статті наголошено, що одним із засобів урегулювання трудових і пов'язаних із ними правовідносин $\epsilon$ кодифікація трудового законодавства, адже натепер Україна - чи не єдина посткомуністична країна, яка користується Кодексом законів про працю, прийнятим ще в 1971 році. Незважаючи на те що до вказаного нормативно-правового акта за п'ятдесят років унесено низку змін і доповнень, у ньому залишається чимала кількість прогалин, адже більшість його норм $\epsilon$ застарілими та не відповідають наявним реаліям. На основі аналізу наукових поглядів учених визначено, як розвивалося трудове законодавство України за часів існування СРСР. Обгрунтовано, що окреслений у статmі історичний етап можна поділити на п'ять підетапів. Відзна чено, що трудове законодавство України в період існування СРСР характеризувалося певною нестабільністю та протиріччями, що пов'язано з особливостями соціально-економічного розвитку держави. 3'ясовано, що основна увага в трудовому кодексі 1918 року акцентувалася на охороні праці, реалізація якої була покладена на інспекцію праці, технічну інспекцію та представників санітарного нагляду, а саме здійснення контролю за точним дотриманням правових норм Кодексу (декретів, інструкцій і розпоряджень), що регулюють питання охорони праці й здоров'я працюючих. Окрім того, вагомим аспектом розділу охорони праці було встановлення трудової дисципліни, порушення якої каралося різними видами стягнень, що встановлювалися керівництвом підприємства. Визначено, що новий етап розвитку трудового законодавства України починається з 1991 року, коли наша країна визнана незалежною державою. Із цього періоду в Кодекс законів про працю внесено понад 100 змін, які зумовлені переходом України до ринкової економіки, що потребувало домінування договірного регулювання суспільних відносин у сфері найманої праці. Зроблено висновок, що трудове законодавство України в період існування СРСР характеризувалося певною нестабільністю та протиріччями, що пов'язано з особливостями соціально-економічного розвитку держави.

Ключові слова: законодавство, історичний розвиток, трудове законодавство, СРСР, нормативно-правові акти.

В статье отмечено, что одним из средств урегулирования трудовых и связанных с ними правоотношений является кодификация трудового законодательства, ведь на сегодняшний день Украина - едва ли не единственная посткоммунистическая страна, которая пользуется Кодексом законов о труде, принятым еще в 1971 году. Несмотря на то, что в указанный нормативно-правовой акт за пятьдесят лет внесен ряд изменений и дополнений, в нем остается достаточно большое количество пробелов, ведь большинство его норм являются устаревшими и не соответствуют существующим реалиям. На основе анализа научных взглядов ученых определено, как развивалось трудовое законодательство Украины во времена существования СССР. Обосновано, что очерченный в статье исторический этап можно разделить на пять подэтапов. Отмечено,

Обушенко Н. М., 2019 что трудовое законодательство Украины в период существования СССР характеризовалось определенной нестабильностью и противоречиями, что связано с особенностями социально-экономического развития государства. Установлено, что основное внимание в трудовом кодексе 1918 года акцентировалось на охране труда, реализация которой была возложена на инспекцию труда, техническую инспекцию и на представителей санитарного надзора, в частности это осуществление контроля за точным соблюдением правовых норм Кодекса (декретов, инструкций и распоряжений), регулирующих вопросы охраны труда и здоровья работающих. Кроме того, весомым аспектом раздела охраны труда было установление трудовой дисциплины, нарушение которой каралось различными видами взысканий, которые устанавливались руководством предприятия. Определено, что новый этап развития трудового законодательства Украины начинается с 1991 года, когда наша страна признана независимым государством. С этого периода в Кодекс законов о труде внесено более 100 изменений, которые обусловлены переходом Украины к рыночной экономике, что требовало доминирования договорного регулирования общественных отношений в сфере наемного труда. Сделан вывод, что трудовое законодательство Украины в период существования СССР характеризовалось определенной нестабильностью и противоречиями, что связано с особенностями социально-экономического развития государства.

Ключевые слова: законодательство, историческое развитие, трудовое законодательство, СССР, нормативно-правовые акты.

Emphasized that he is one of those who work and exercise his rights, the codification of the labor law that remains in Ukraine today - is not a post of a post-communist state that uses the Labor Code, and certainly should be in 1971 year. Despite the fact that it points to the legal urgency for the fiftieth anniversary, it has been amended and supplemented in that it remains a pure gap, many of its rules are outdated and do not really need to be implemented. In our view, scientific analysts are considering, but as Ukraine's labor law has evolved, during the Soviet Union. It is justified that separately in the historical period it was possible to divide into sub-stages. Determining that the labor legislation of Ukraine during the existence of the USSR was secured to a certain extent by the instability and contradictions achieved by socio-economic development. It was found that the main focus of the 1918 Labor Code was on labor protection, implementation was on labor inspection, technical inspection and health inspection, but this was in order to comply with the legal provisions of the Code (decrees, relevance and need) governing work and health issues. Precisely, a significant aspect was that employees were established by discipline, and those who were of different kinds were attained, and that was the management of the enterprise. It has been determined that the new expansion of the labor legislation of Ukraine began in 1991, when our country was known as an independent state. Since that time, the Labor Code Codes have nearly 100 times been collected for Ukraine's transition to a market economy, which required a change in the contractual regulation of public rela- 


\section{Проблеми трудового права та права соціального забезпечення}

tions at the lowest level. It is made appropriate that the labor legislation of Ukraine during the Soviet Union remains a certain unstable and opposite, which was known from the socio-economic development.

Key words: legislation, historical development, labor law, USSR, regulatory acts.

Постановка проблеми та іï актуальність. Сучасні соціально-економічні й політичні умови, які склалися в нашій країні, а також виникнення нових професій і підвищення трудової мобільності громадян від законодавця вимагають пошуку нових засобів для врегулювання трудових і пов'язаних із ними правовідносин. Одним із таких засобів $\epsilon$ кодифікація трудового законодавства, адже натепер Україна - чи не єдина посткомуністична країна, яка користується Кодексом законів про працю, який прийнято ще в 1971 році. Незважаючи на те що до вказаного нормативно-правового акта за п'ятдесят років унесено низку змін і доповнень, у ньому залишається чимала кількість прогалин, адже більшість його норм $€$ застарілими та не відповідають наявним реаліям. Утім, перш ніж переходити безпосередньо до аналізу напрямів удосконалення трудового законодавства, окрему увагу варто приділити історії його становлення й розвитку. При цьому варто вказати, що формування ж українського трудового законодавства пов'язано зі становленням нашої держави, зокрема радянським періодом ії історії.

Аналіз останніх досліджень і публікацій. Окремі проблемні питання становлення та розвитку трудового законодавства України вже неодноразово потрапляли в поле зору різних науковців. Зокрема, їм приділяли увагу П.Д. Пилипенко, В.Я. Бурак, З.Я. Козак, П.П. Музиченко, В.В. Копєйчиков, С.В. Пєтков, Г.О. Спіцина, С.М. Прилипко, О.М. Ярошенко, В.В. Жернаков, О.І. Кисельова, Н.П. Долгіх і багато інших. Утім, незважаючи на чималу кількість наукових здобутків, єдиного комплексного дослідження, присвяченого історичному розвитку трудового законодавства, зокрема за часів існування СРСР, так і не проведено.

Саме тому метою статті $€$ надати характеристику тому, як відбувався розвиток трудового законодавства України за часів існування СРСР.

Виклад основного матеріалу. На початку існування СРСР прийнято перший Кодекс законів про працю (1918 рік), який здебільшого мав декларативний (описовий) характер і відсутність контролю за його виконанням. Головне завдання Кодексу полягало у вирішенні питань «воєнного комунізму», за якого трудові відносини регулювалися загальними трудовими повинностями. Припинення дієвості кодексу пов'язано з появою нової економічної політики (непу) держави, що призвело до виникнення обмеженої приватної власності, яка анулювала ефективність трудової повинності як форми реалізації трудових відносин. Український трудовий кодекс того часу (1918-1929 роки) включав такі положення: восьмигодинний робочий день і щотижневий відпочинок (42 години); відсутність нічних змін, крім певних галузей народного господарства; заборона на використання праці підлітків до 16 років і надання спеціального робочого графіку для них: робочий день становить не більше ніж шість годин; обмеження жіночої праці на шкідливих підприємствах; передбачення декретних відпусток; створення бірж праці; запровадження державної страхової системи робітників за рахунок підпри- ємців; створення спеціальних судів для розгляду трудових спорів і виборної інспекції праці [1]. Основною формою регулювання трудових відносин того періоду був колективний договір, основні положення якого розкрито у законі «Про порядок затвердження колективних договорів (тарифів), що встановлюють ставки заробітної плати й умови праці» від 2 липня 1918 року. У контексті цього важливими $є$ дослідження Л.С. Таля, який писав, що «з другої половини XIX століття дієвості набуває тенденція публічно-правової повинності обов' язків роботодавця, від виконання якої він не може звільнитися за домовленістю з працівником» [2, с. 6-9]. Такий вектор регулювання трудових відносин розкриває сутність Кодексу 1918 року, яким фактично передбачено несамостійний характер праці, за якої працівник підпорядковується господарській владі та внутрішньому розпорядку підприємства. Останнє є свідченням того, що до головних умов трудового договору того часу належали приватний порядок угоди сторін і публічний порядок регулювання трудових відносин, що визначається нормами закону [2].

Варто також відмітити, що основна увага в Кодексі 1918 року акцентувалася на охороні праці, реалізація якої була покладена на інспекцію праці, технічну інспекцію й представників санітарного нагляду, зокрема здійснення контролю за точним дотриманням правових норм Кодексу (декретів, інструкцій і розпоряджень), що регулюють питання охорони праці та здоров'я працюючих. Окрім того, вагомим аспектом розділу охорони праці було встановлення трудової дисципліни, порушення якої каралося різними видами стягнень, що встановлювалися керівництвом підприємства. Прикладом цього слугують постанови колективів деяких підприємств, які були спрямовані на позбавлення на певний термін продовольчого пайка; зниження премії; вирахування із заробітної плати; передачу розгляду провини дисциплінарному товариському судові; звільнення тощо. Вищезазначені заходи використовувалися також з метою посилення трудової дисципліни. Кодекс законів про працю УСРР був ефективним інструментом регулювання трудових відносин для того часу. Із цього приводу В.М. Догадов пише: «Законодавство про працю мало надати трудящим тільки мінімум гарантій прав, указуючи ту межу, нижче за яку не повинні опускатися умови праці ні в одному підприємстві, установі або господарстві» [3].

У 1922 році розроблено та прийнято новий Кодекс законів про працю, який був покликаний підвищити якість та ефективність захисту трудових прав працівників. У зв'язку з політичними змінами 1924 року в Україні розпочинається посилена централізація державного управління, яка потребувала підвищення рівня трудової дисципліни. Наслідком цього $є$ прийняття постанов, націлених на боротьбу з порушниками трудової дисципліни: «Про заходи щодо зміцнення трудової дисципліни на державних підприємствах» від 6 березня 1929 року, «Про заходи щодо поліпшення виробничого режиму та зміцнення трудової дисципліни на підприємствах» від 5 липня 1929 року. Результатами цих постанов було створення скороченого календарно-робочого тижня (на безперервно діючих підприємствах та установах п'ятиденний, на всіх інших - шестиденний) [4, с. 40].

Наступний етап становлення трудового законодавства України припадає на 1930-ті роки, які характери- 
зуються домінуванням загальносоюзного законодавства над республіканським, де регулювання відбувається шляхом використання союзних нормативних актів, а 3 іншого - дублюванням республіканським законодавством змісту загальносоюзних законодавчих актів. На початку 30-х років переглянутий i доповнений Кодекс законів про працю УСРР 1922 року. Зміни торкнулися таких положень: переведення робітників промисловості й транспорту на 7-годинний робочий день; підприємства переведено на безперервний робочий тиждень; уведено систему «плаваючий вихідний день» (отримання вихідного дня в різні дні тижня); нарахування заробітної плати регулювалося професійною кваліфікацією робітника; фіксованими ставками або за тарифними сітками; уведено основні формами оплати: відрядну, почасову й преміальну [5]. Особлива увага, як і раніше, приділялася забезпеченню жорсткої трудової дисципліни робітників і службовців. Так, відсутність на робочому місці без поважної причини протягом одного дня каралася звільненням із роботи з позбавленням права користуватися житлом, наданим підприємством. В окремих сферах народного господарства СРСР прийнято положення про дисципліну на залізничному транспорті (1933 рік), в органах юстиції (1933 рік), на водному транспорті (1934 рік), в органах зв'язку (1935 рік), які містили більш жорстоку відповідальність окремих категорій працівників [1].

Чергові зміни в трудовому законодавстві України відбулися з підписанням нової Конституції УРСР (1937 рік), де встановлені нові положення організації праці. До них належали право кожного на працю й усунення загальної трудової повинності. Останнє свідчило про усунення експлуататорських класів і визиску людини в державі. Однак варто зазначити, що ці положення реалізовані лише на папері та відсутні в практиці. Цей історичний період характеризує початок масових репресій, де не дотримувалися трудові та інші права громадян. Отже, 1936-1938 роки символізують нестабільність політичної сфери держави: з одного боку, номінальне створення конституційних прав і свобод громадян і законодавчі та фактичні гарантії їх реалізації, а з іншого - відсутність забезпечення цих норм (жорсткі умови праці й суворе дотримання трудової дисципліни). Останнє сприяло регресії професійної сфери держави, «витоку розуму» за кордон [6].

3 метою зміцнення трудової дисципліни 20 грудня 1938 року, згідно з постановою РНК СРСР, створені трудові книжки, головна мета яких полягала в обліку робітників і службовців у всіх державних і кооперативних підприємствах, установах та організаціях. Трудові книжки містили основні відомості про працівника: прізвище, ім'я по батькові, вік, освіта й професія; загальні відмітки про його трудову діяльність (місце роботи, перехід з однієї установи до іншої та причини переходу, відзнаки й нагороди). Окремою категорією зазначалася причина звільнення, яка співвідносилася з посиланням на статтю Кодексу законів про працю (пункт), тобто відповідати певним положенням закону [7].

Вагомий вплив на становлення та розвиток трудового законодавства України мав період Великої Вітчизняної війни, який активізував тенденції в бік погіршення становища працівників. У контексті цього дослідник П.П. Музиченко відмічає: «Потреба оборони призвели до необхідності введення трудових мобілізацій і трудової повинності. Трудовій мобілізації підлягало працездатне населення міст з числа тих, хто не працював у державних установах і на підприємствах. Мобілізовані направлялися на важливі виробництва й будови за місцем проживання. Трудова повинність використовувалася для виконання будівельних робіт на оборонних спорудах, заготівлі палива, охорони шляхів сполучення, зв'язку, електростанцій та інших важливих об'єктів, що мали оборонне значення. Трудова повинність поширювалася на чоловіків від 16 до 55 років, а жінок від 16 до 50 років» [8, с. 376]. Процес мобілізації був обов'язком для всього працездатного населення, ухилення від якого каралося суворо - притягнення до кримінальної відповідальності. Водночас пріоритетним завданням також залишалося посилення трудової дисципліни (подвійна відповідальність за самовільне звільнення робітників). Суворо каралися, особливо в умовах війни, прогули без поважних причин [8, с. 376].

Настання мирного часу (закінчення війни) створило всі умови для ефективної праці та відмови від способів регулювання трудових відносин воєнного часу. Прикладом цього $\epsilon$ скасування трудової мобілізації й установлення процесу організованого набору робочої сили на підставі договорів між роботодавцем і працівником, ліквідація щоденних тригодинних понаднормових робіт, відновлення запланованих і додаткових відпусток, виплата відпускних, які не були реалізовані у воєнний період.

Наступний етап становлення сучасного трудового законодавства пов'язаний із рішенням Президії Верховної Ради СРСР від 8 березня 1956 року про впровадження скорочення робочого дня в передвихідні й передсвяткові дні на дві години. У 1958 році видано указ про встановлення семигодинного робочого дня, за яким функціонувала більша частина підприємств та установ. У цей період установлено тимчасове пом'якшення норм трудового законодавства [9]. Однак процес централізації державного механізму (системи органів влади й управління, правоохоронних органів) вплинув на виникнення тенденції централізації законодавчої влади. Згідно із законом від 1 лютого 1957 року, модифікація права визначила межі законотворчої самостійності радянських республік. Так, на союзному рівні - це Основа законодавства Союзу РСР і союзних республік, на республіканському - кодекси всіх галузей права. Результатом цього виду діяльності стало видання Зводу законів СРСР і Зводу законів Української РСР [10].

Узагальнюючи вищезазначений матеріал, можна зробити висновок, що період післявоєнного часу й до початку 1970-х років трудове законодавство перебувало в процесі постійного розвитку та вдосконалення в унісон економіко-соціальних потреб тогочасного суспільства. Упровадження певних трудових норм (восьмигодинний робочий дня, уведення обов'язкового медичного огляду тощо) стало основним базисом сучасного трудового законодавства України.

На початку 1970-х років створено новий Кодекс законів про працю УРСР, базисом для якого слугували раніше розроблені положення та перевірені на практиці. У цьому випадку мова йде про участь працівників у функціонуванні виробництва, матеріальну винагороду, робочий час. Реформування законодавства торкнулося юридичних гарантій прав робітників: 
визначення обов'язків роботодавця та працівника в процесі укладання трудового договору, який може мати усну або письмову форму. Працевлаштування підтверджується створенням наказу (розпорядженням) підприємством з подальшим ознайомленням працівника з ним під розписку. Таким спосіб прийому на роботу (підписання трудового договору) вперше визнано офіційним допущенням до роботи, незалежно від того чи був процес працевлаштування оформлений належним чином. Нововведенням трудового законодавства було створення положення, відповідно до якого підприємство не має права відмовити працівнику в укладанні трудового договору, що переведений з іншої установи за згодою між керівниками підприємств [11].

Кодекс законів про працю цього періоду містив перелік обов'язків керівництва підприємств у сфері матеріального розрахунку робітника, що звільняється (статті 36, 38, 39 тощо). У Кодексі законів про працю містився розділ, де зазначався термін проведення розрахунку й законодавчі наслідки затримки розрахунку з вини адміністрації. Реформування набули положення про обмеження залучення до нічних робіт окремих категорій працівників (ст. 48), про неповний робочий час (ст. 49), про змінну роботу (ст. 52), про залучення працівників до понаднормових робіт [12].

Змін набули положення відносно умов і правил відпочинку працівників. Прикладом цього $є$ дозвіл на трудову діяльність у вихідні дні лише зі згоди профспілкової організації з метою забезпечення охорони праці (ліквідація стихійного лиха, виробничої аварії, запобігання нещасним випадкам, псування державного або суспільного майна тощо); сформульовані правила розрахунку стажу роботи, що дає право на відпустку (ст. 72); порядок надання й використання відпусток (статті 73, 74). Питання щодо заробітної плати стосувалися системи оплати праці, винагороди за підсумками роботи протягом року, розміру матеріального заохочення під час виготовлення бракованої продукції (ст. 93), часу простою (ст. 94) [12].

Розробка Основ законодавства про працю та певні нововведення у сфері трудового законодавства сприяли появі Положення про порядок розгляду трудових спорів від 24 травня 1974 року. Сутність цього нормативного акта полягала в розширенні сфери впливу профспілок під час вирішення трудових спорів [13].

Однак уже в серпні 1983 року внесені зміни в трудове законодавство згідно з рішенням Президії Верховної Ради СРСР, які були спрямовані на відновлення посилення трудової дисципліни, що було типовим для командно-адміністративної системи. Останнє сприяло виникненню певних порушень у сфері прав людини, що деструктивно впливало на ефективність праці, знижувало працездатність робітників і впливало на якість роботи [14].

Період «Перебудови» (1985-1991 роки) в історії нашої держави зумовив необхідність змін у трудовому законодавстві, що призвело до розроблення нового порядку розроблення й укладення колективних договорів, ліквідовано низку законодавчих обмежень, визначено тривалість випробувального терміну під час прийому - за згодою сторін трудового договору. Були розроблені та прийняті нові закони СРСР: «Про власність в СРСР», «Про підприємства в СРСР», «Про кооперацію в СРСР» тощо. В українському трудовому законодавстві було продубльовано закони «Про власність», «Про підприємства в УРСР», «Про зайнятість населення», «Про основи соціальної захищеності інвалідів в УРСР» [15].

Лютий 1986 року характеризується початком процесу демократизації трудового права й розробленням законодавства щодо потреб ринкової економіки, що анулювала застарілі норми та положення, затвердженням інновацій у сфері трудової дисципліни [16]. Вищезазначені реформи були відображені в Основах законодавства Союзу РСР і республік про зайнятість населення від 15 січня 1991 року, основною метою цього положення було визнання свободи праці та права на добровільне безробіття, скасування адміністративного примус до праці. Головною інновацією законодавства того часу було право громадян на трудову зайнятість за кордоном. Останні зміни торкнулися законів стосовно порядку звільнення працівників, видів дисциплінарних стягнень, порядку вирішення індивідуальних трудових конфліктів [16].

Узагальнюючи вищезазначений матеріал, проциту$\epsilon м о$ дослідників Є.Б. Хохлова та С.П. Мавріна, з якими ми згодні в тому, що «до кінця XX століття почало складатися законодавство, спрямоване на регулювання праці окремих категорій працівників, насамперед дітей і жінок. Як правило, норми цього законодавства зводилися до обмеження (нормування) тривалості робочого часу, а також до заборони застосування дитячої й жіночої праці на окремих роботах» [17, с. 31]. Отже, Кодекс законів про працю України 1971 року став базисом для розвитку сучасного трудового законодавства країни, оскільки воно мало вже сформовані інститути трудового права, які включали основні гарантії трудових прав та інтересів представників трудових правовідносин, які є дієвими й нині.

Новий етап розвитку трудового законодавства України починається з 1991 року, коли наша країна визнана незалежною державою. Із цього періоду в Кодекс законів про працю України внесено понад 100 змін, які зумовлені переходом України до ринкової економіки, що потребувало домінування договірного регулювання суспільних відносин у сфері найманої праці. Однак при цьому варто відмітити, що реальних і дієвих механізмів реалізації договірного регулювання праці на початку дев' яностих років так не створено.

Висновки. Узагальнюючи весь наведений у науковому дослідженні матеріал, маємо можливість виділити такі основні підетапи розвитку системи трудового законодавства України в період існування СРСР:

1) 1918-1921 роки - відзначається розробленням і затвердженням першого Кодексу законів про працю як законодавчої форми врегулювання трудових відносин. Однак Кодекс мав низку певних недоліків, а норми трудового законодавства мали формальний (декларативний) характер;

2) 1922-1939 роки - створення другого Кодексу законів про працю, що має прогресивний характер для того часу. У цей історичний період закладено основи для оформлення трудового договору;

3) 1940-1945 роки - припадає на часи Великої Вітчизняної війни, унаслідок чого розвиток трудового законодавства характеризується його погіршенням, оскільки значно посилено вимоги до дисципліни праці та санкцій за її порушення; 


\section{та права соціального забезпечення}

4) 1945-1970 роки - повоєнний час: відновлюються трудові права робітників, поступове оновлення й удосконалення трудового законодавства;

5) 1971-1990 роки - затвердження третього Кодексу законів про працю, результатом якого $€$ створення основи системи трудового законодавства сучасної України;

На завершення хотілося б підсумувати, що трудове законодавство України в період існування СРСР характеризувалося певною нестабільністю та протиріччями, що пов'язано з особливостями соціально-економічного розвитку держави.

\section{Література}

1. Голеня Є.Ф. Радянське трудове право : курс лекцій. Київ : Київський інститут народного господарства, 1964.

2. Таль Л.С. Очерки промышленного рабочего права. 2-е издание, значительно дополненное. Москва : Московское научное издательство, 1918. 225 с.

3. Догадов В.М. Очерки трудового права. Москва : Прибой, 1927. С. 16.

4. Томашевский К.Л. Очерки трудового права (История, философия, проблемы систем и источников) / науч. ред. О.С. Курылева. Минск : Изд. центр БГУ, 2009. 335 с.

5. Пастухов В.П. Радянське трудове право. Київ : Радянська школа, 1989.

6. Чанишева Г. Окремі теоретичні проблеми сучасного трудового права України. Право України. 1999. № 9. С. 13-19.

7. Венедиктов В.С. Трудовое право Украины : учебное пособие. Харьков : Консум, 2006. С. 10.
8. Музиченко П.П. Історія держави і права України : навчальний посібник. 6-те видання, перероблене й доповнене. Київ : Знання, 2007. 471 с.

9. Абрамова О.В. Советское трудовое право. Москва : Высшая школа, 1988. С. 42.

10. Трудове право України: Академічний курс : підруч. для студ. юрид. спец. вищ. навч. закл. / П.Д. Пилипенко, В.Я. Бурак, З.Я. Козак та ін. ; за ред. П.Д. Пилипенка. 2-е видання, перероблене й доповнене. Київ : Видавничий Дім «Ін Юре», 2006. 544 с.

11. Трудове право України / за ред. Н.Б. Болотіної й Г.І. Чанишевої. Київ : Товариство «Знання», 2000.

12. Кодекс законів про працю прийнятий від 10.12.1971, електронне джерело з останніми змінами від 09.12.2012.

13. Иванов С.А. Трудовое право переходного периода: новые источники. Государство и право. 1996. № 1. С. 43-52.

14. Правознавство / за ред. В.В. Копєйчикова. Київ : Юрінком Інтер, 2002.

15. Погорілко В.Ф. Радянське трудове право : навчальний посібник. Київ : Політвидав України, 1984. С. 8.

16. Гончаров Г.Ю. Історія становлення та розвитку інституту дисципліни праці. Науковий вісник Міжнародного гуманітарного університету. Серія «Юриспруденція». 2014. № 10-1. Том 2. С. 38-40.

17. Трудовое право России : учебник / под ред. С.П. Маврина, Е.Б. Хохлова. Москва : Юристъ, 2002. 560 с.

Обушенко Н. М., кандидат юридичних наук, старший науковий співробітник секретаріату вченої ради Дніпропетровського державного університету внутрішніх справ 